\title{
Assessing genetic diversity in 23 early Polish oat cultivars based on molecular and morphological studies
}

\author{
M. Boczkowska $\cdot$ J. Nowosielski • \\ D. Nowosielska $\cdot$ W. Podyma
}

Received: 5 August 2013/Accepted: 13 January 2014/Published online: 12 February 2014

(C) The Author(s) 2014. This article is published with open access at Springerlink.com

\begin{abstract}
In Poland oat breeding began at the late nineteenth century. During the World War II almost all of Polish breeding materials were lost, and then were replaced by German cultivars. The main aim of this paper was to show the level of genetic diversity of Polish oat cultivars which were bred before 1939 . Simultaneously usefulness and informativeness of molecular and morphological methods were tested and compared. This study involved 23 cultivars, which were described by 25 morphological traits and three types of molecular markers (AFLP, ISSR and RAPD). Based on Dice coefficient, genetic distance between cultivars ranged from 0.17 to 0.44 . The degree of morphological differentiation within the collection varied depending on trait. Nei's genetic diversity for the combined results for the whole collection was equal to 0.202 . Neither unweighted pair group method with arithmetic mean nor principal coordinate analysis showed any discrimination of cultivars according to breeding period and morphological trait. Part of morphological diversity has been preserved in the
\end{abstract}

M. Boczkowska ( $₫) \cdot$ J. Nowosielski .

D. Nowosielska · W. Podyma

Plant Breeding and Acclimatization Institute (IHAR) -

National Research Institute, 05-870 Radzików, Poland

e-mail: maja.boczkowska@gmail.com

Present Address:

D. Nowosielska

Ministry of Agriculture and Rural Development, Warsaw, Poland
Polish early oat cultivars, do not exist anymore in contemporary cultivars, and also in landraces. The interest of breeders in early cultivars germplasm stored in genebank was and still is negligible. Breeding is confined to a few preferred by market morphotypes. So, it is very probable that the gene pools of early and contemporary cultivars could be separable.

Keywords AFLP - Avena sativa $\cdot$ Genetic diversity $\cdot$ ISSR $\cdot$ Morphology $\cdot$ RAPD

\section{Introduction}

Oat is considered as a crop with comparatively short cultivation history. Its cultivation began several 1,000 years later than wheat or barley. It is defined as a secondary crop because for many centuries it was mostly present as a weed in the emmer wheat (Triticum dicoccum L.) fields (Vavilov 1992). In contrast to wheat and barley, archaeological research did not show that oat was known in ancient Egypt, Greece or Rome. The beginning of oat cultivation dates back to the beginning of Christianity (Warburton 1910). Along with wheat and barley, oat migrated from Asia Minor to the North (Loskutov 2008). Due to greater coldresistance and adaptation to poor soil it gradually transformed into a separate crop. In Europe hexaploid oats were domesticated at the turn of the Bronze and Iron Age (Ladizinski 1988; Leggett and Thomas 
1995). However, for a long time it was grown as livestock feed and was used as food only in times of famine. Oat entered the human diet along with the development of milling machines. In Poland, oat cultivation probably began in the early Middle Ages (Jasińska 2003).

Oat breeding history in Poland started at the end of the nineteenth century. Till the beginning of the World War II around 60 cultivars were bred. Some of them were so successful that were cultivated continuously up to the $70 \mathrm{~s}$ of the twentieth century. During the war almost all Polish breeding materials were destroyed. Shortly after the war German cultivars became the basis of Polish breeding programs (Świerczewski and Mazaraki 1993). After investigating the Polish breeding history pedigrees of the material, knowledge of the genetic diversity of the early cultivars collection became obvious. Possibly, some useful alleles which had been lost in the course of recent breeding could be useful for future breeding.

The present study was designed to answer three major questions: (a) What level of diversity occurred within the collection of Polish primary oat cultivars? (b) Are the results for diversity assessments obtained by different techniques are compatible? (c) Which molecular markers are the most useful in estimating genetic diversity of a common oat collection?

\section{Materials and methods}

\section{Plant material}

The plant material of the presented study was a collection of 23 primary cultivars of common oat which were bred in Poland before 1939. Six of them were bred prior to 1914 , and the remaining 17 in the period 1918-1939 (Table 1). All of accessions come from the collection of the National Centre for Plant Genetic Resources, the Plant Breeding and Acclimatization Institute-National Research Institute at Radzików, Poland, and were placed in the genebank in 1985-1994. Each accession was represented by a bulk sample.

\section{Molecular marker analysis}

Bulk DNA was isolated from young healthy leaf tissue separately for each accession using CTAB procedure
(Murray and Thompson 1980) for AFLP and RAPD analysis and using the Genomic Mini AX Plant (A \& A Biotechnology) for ISSRs. Genome DNA analyses of 23 oat cultivars were carried out with the use of AFLP (Boczkowska et al. 2012), ISSR (Boczkowska and Tarczyk 2013) and RAPD (Wiśniewska and Rafalski 2006) methods. The complete list of primers used in the study is included in the Table 2.

Morphology analysis

The analysis was carried out on 20 randomly chosen plants for each accession. 25 morphological traits such as: growth habit, hairiness of leaf sheath, spirality of leaves, intensity of leaves spirality, rigidity of leaves, angle to culm of leaves, angle of flag leaf to culm, hairiness of leaf margin, color of leaves, color of panicle, nodes hairiness, shape of panicle, type of panicle, lemma color, axis nodes in panicle, erectness of spikelets, number of grains in spikelet, awnedness, awn type, hairiness of basal part of the primary grain, hairiness of lemma, hairiness of rachilla, length of rachilla, shape of basal part of the primary grain, shape of primary grain had been examined (Table 3 ). The morphological traits were set on the base of descriptors described by Slabonski (1949), IBPGR (1985) and UPOV (1994). Botanical variety was determined according to the classification of Rodionova et al. (1994)

\section{Data analysis}

The length of amplified fragments and morphological traits results were transformed into a binary matrix, where 1 indicated the presence and 0 absence of a fragment/trait. Genetic distance was calculated based on the Nei's formula (Nei 1978). Mantel test (Mantel 1967) with 999 permutations was conducted to compare dissimilarity matrices. Multidimensional scaling principal coordinate analysis (PCoA) and cluster analysis using UPGMA (unweighted pair group method with arithmetic mean) were performed. In order to estimate genetic variation within the groups of cultivars created basing on the breeding period the Nei's coefficient (Lynch and Milligan 1994) and the Shannon's index (Brown and Weir 1983) were calculated. For these two coefficients Pearson's correlation analysis was performed. Analysis of molecular variance (AMOVA) for the groups was also performed (Excoffier et al. 1992). 
Table 1 List of cultivars analysed with some basic information

\begin{tabular}{|c|c|c|c|c|c|}
\hline No. & Cultivar name & $\begin{array}{l}\text { Accession } \\
\text { number }\end{array}$ & Botanical variety & Breeding period & Pedigree \\
\hline 1 & Antoniński Żółty & 51902 & aurea Körn. & 1918-1939 & Selection of Żółty Lochowa \\
\hline 2 & Biały Mazur & 51466 & mutica Alef. & Before 1914 & Landrace $\times$ Biały Orzeł \\
\hline 3 & Duppawski & 51167 & $\begin{array}{l}\text { mutica Alef., } \\
\text { aurea Körn. }\end{array}$ & 1918-1939 & $\begin{array}{l}\text { Selection of landrace from } \\
\text { Czech Republic }\end{array}$ \\
\hline 4 & Grzywacz Późny Wołyński & 50788 & flava Körn. & 1918-1939 & $\begin{array}{l}\text { Selection of Marczak } \\
\text { Włościański }\end{array}$ \\
\hline 5 & Jagiełło & 51507 & $\begin{array}{l}\text { mutica Alef., aristata } \\
\text { Krause }\end{array}$ & 1918-1939 & Selection of Rychlik Mikulicki \\
\hline 6 & Kanarek Mikulicki & 51510 & $\begin{array}{l}\text { mutica Alef., aristata } \\
\text { Krause, aurea Körn. }\end{array}$ & $1918-1939$ & Selection of Jagiełło \\
\hline 7 & Kościelecki & 50334 & $\begin{array}{l}\text { mutica Alef., aristata } \\
\text { Krause }\end{array}$ & 1918-1939 & $\begin{array}{l}\text { Selection of Marczak } \\
\text { Włościański }\end{array}$ \\
\hline 8 & Lubelski & 51166 & mutica Alef. & Before 1914 & No data \\
\hline 9 & $\begin{array}{l}\text { Niemierczański } \\
\text { Najwcześniejszy }\end{array}$ & 51084 & aurea Körn. & Before 1914 & $\begin{array}{l}\text { Selection of local cultivar from } \\
\text { Podole }\end{array}$ \\
\hline 10 & Ozimowy & 51087 & $\begin{array}{l}\text { mutica Alef., aristata } \\
\text { Krause }\end{array}$ & Before 1914 & No data \\
\hline 11 & Podkowa Dłużewski & 51227 & $\begin{array}{l}\text { mutica Alef., aristata } \\
\text { Krause }\end{array}$ & 1918-1939 & Selection of Leutewicki \\
\hline 12 & Puławski Sredniowczesny & 50406 & aurea Körn. & $1918-1939$ & Selection of Pfiffelbacher Gelb \\
\hline 13 & Puławski Wczesny & 51232 & aurea Körn. & 1918-1939 & $\begin{array}{l}\text { Selection of landrace from } \\
\text { Siedleckie }\end{array}$ \\
\hline 14 & Rychlik Kozarowski & 51237 & grisea Körn. & $1918-1939$ & $\begin{array}{l}\text { Selection of local cultivar from } \\
\text { Kozarowszczyzna }\end{array}$ \\
\hline 15 & Rychlik Oberek & 51233 & aurea Körn. & 1918-1939 & Rychlik Podgórski $\times$ Iogold \\
\hline 16 & Rychlik Trybański & 51235 & aurea Körn. & $1918-1939$ & $\begin{array}{l}\text { Selection of Złoty Rychlik } \\
\text { Lubelski }\end{array}$ \\
\hline 17 & Sobieszyński & 51261 & $\begin{array}{l}\text { mutica Alef., aristata } \\
\text { Krause }\end{array}$ & Before 1914 & Selection of Rychlik Lubelski \\
\hline 18 & Sołacki Wczesny & 50581 & $\begin{array}{l}\text { mutica Alef., aristata } \\
\text { Krause }\end{array}$ & 1918-1939 & $\begin{array}{l}\text { Selection of local cultivar from } \\
\text { Sandomierszczyzna }\end{array}$ \\
\hline 19 & Tatrzański & 50975 & $\begin{array}{l}\text { mutica Alef., aristata } \\
\text { Krause }\end{array}$ & $1918-1939$ & $\begin{array}{l}\text { Selection of landrace from } \\
\text { Podhale }\end{array}$ \\
\hline 20 & Teodozja & 50976 & aurea Körn. & Before 1914 & Selection of Scotish oat \\
\hline 21 & Udycz Biały & 51051 & grisea Körn. & $1918-1939$ & $\begin{array}{l}\text { Kanarek } \\
\text { Mikulicki × Zwycięzca } \\
\text { (from Niemierczański } \\
\text { Najwcześniejszy) }\end{array}$ \\
\hline 22 & Udycz Żółty & 51050 & aurea Körn. & 1918-1939 & Żółty Pfluga × Żółty Lochowa \\
\hline 23 & Zielony & 50869 & $\begin{array}{l}\text { obtusata Alef. tartarica } \\
\text { Ard. }\end{array}$ & 1918-1939 & $\begin{array}{l}\text { Selection of landrace from } \\
\text { Wołyń }\end{array}$ \\
\hline
\end{tabular}

For all markers analysis of performance was carried out. Polymorphic information content (PIC), which is a relative measure of marker informativeness and depends on the number of alleles of particular marker, and their frequency in the population, was calculated according to the formula described by Roldan-Ruiz et al. (2000). Marker Index (MI), which can provide a convenient estimate of marker utility was estimated 
Table 2 List of primers used in the study and informativeness coefficients values

\begin{tabular}{|c|c|c|c|c|c|c|c|c|c|}
\hline Marker type & Primer name & $\begin{array}{l}\text { Sequence } \\
5^{\prime} \rightarrow 3^{\prime}\end{array}$ & Marker name & $\mathrm{NF}^{\mathrm{a}}$ & $\% \mathrm{PF}^{\mathrm{b}}$ & $\mathrm{PIC}^{\mathrm{c}}$ & $\mathrm{EMR}^{\mathrm{d}}$ & $\mathrm{MI}^{\mathrm{e}}$ & $R P^{f}$ \\
\hline \multirow[t]{8}{*}{ AFLP } & EcoRI-ACT & GACTGCGTACCAATTCACT & AFLP1 & 35 & 62.86 & 0.23 & 13.83 & 3.16 & 11.04 \\
\hline & MseI-CAA & GATGAGTCCTGAGTAACAA & & & & & & & \\
\hline & EcoRI-AAG & GACTGCGTACCAATTCAAG & AFLP2 & 24 & 70.83 & 0.23 & 12.04 & 2.75 & 7.74 \\
\hline & MseI-CAC & GATGAGTCCTGAGTAACAC & & & & & & & \\
\hline & EcoRI-AAG & GACTGCGTACCAATTCAAG & AFLP3 & 84 & 59.52 & 0.18 & 29.76 & 5.34 & 19.65 \\
\hline & MseI-CAG & GATGAGTCCTGAGTAACAG & & & & & & & \\
\hline & EcoRI-AAG & GACTGCGTACCAATTCAAG & AFLP4 & 88 & 63.64 & 0.22 & 36.05 & 7.81 & 26.17 \\
\hline & MseI-CAT & GATGAGTCCTGAGTAACAT & & & & & & & \\
\hline \multicolumn{2}{|l|}{ Total of AFLP } & & & 231 & 61.47 & 0.21 & 22.92 & 4.77 & 16.15 \\
\hline \multirow[t]{8}{*}{ ISSR } & UBC 807 & AGAGAGAGAGAGAGAGT & ISSR1 & 82 & 68.29 & 0.24 & 38.24 & 9.02 & 26.52 \\
\hline & UBC 825 & ACACACACACACACACT & ISSR2 & 50 & 76.00 & 0.25 & 28.88 & 7.02 & 17.13 \\
\hline & UBC 834 & AGAGAGAGAGAGAGAGYT & ISSR3 & 85 & 76.47 & 0.25 & 49.71 & 12.35 & 28.17 \\
\hline & UBC 841 & GAGAGAGAGAGAGAGAYC & ISSR4 & 67 & 76.12 & 0.26 & 38.82 & 9.93 & 24.35 \\
\hline & UBC 856 & ACACACACACACACACYA & ISSR5 & 49 & 75.51 & 0.25 & 27.94 & 6.98 & 17.13 \\
\hline & UBC 857 & ACACACACACACACACYG & ISSR6 & 59 & 64.41 & 0.21 & 24.90 & 5.16 & 16.09 \\
\hline & UBC884 & HBHAGAGAGAGAGAGAG & ISSR7 & 51 & 84.31 & 0.26 & 36.25 & 9.33 & 17.57 \\
\hline & UBC 885 & BHBGAGAGAGAGAGAGA & ISSR8 & 66 & 72.73 & 0.24 & 34.91 & 8.24 & 21.13 \\
\hline Total of ISSR & & & & 509 & 74.07 & 0.24 & 34.96 & 8.50 & 21.01 \\
\hline RAPD & ET-15 & GACTCGCCAGGTAAG & RAPD & 30 & 80.00 & 0.25 & 19.20 & 4.86 & 11.56 \\
\hline \multicolumn{10}{|c|}{${ }^{a}$ Number of fragments } \\
\hline \multicolumn{10}{|c|}{ b $\%$ of polymorphic fragments } \\
\hline \multicolumn{10}{|c|}{ c Polymorphic information content } \\
\hline \multicolumn{10}{|c|}{${ }^{\mathrm{d}}$ Effective multiplex ratio } \\
\hline \multicolumn{10}{|c|}{ e Marker Index } \\
\hline${ }^{\mathrm{f}}$ Resolving po & & & & & & & & & \\
\hline
\end{tabular}

based on Varshney et al. (2007) formula. It is a product of PIC and effective multiplex ratio (EMR - the number of polymorphic loci in the accession set obtained during experiment). The resolving power (RP), the coefficient that indicates the discriminatory potential of the markers chosen for the analysis was calculated followed the formula of Prevost and Wilkinson (1999). All analyzes were performed using the software FAMD 1.25 (Schlüter and Harris 2006) and GenAlex 6.5 (Peakall and Smouse 2012). A dendrogram was created using the TreeView 1.6.6 (Page 1996).

\section{Results}

Marker informativeness

Using four AFLP primer pairs a total of 231 fragments were obtained of which $62.77 \%$ were polymorphic.
The average number of fragments per pair of primers was 57.8. Participation of polymorphic fragments for each primer combination was relatively equal and was in the range 0.6-0.7 respectively for AFLP3 and AFLP2. During PCR reactions with eight ISSR primers 509 fragments were amplified, out of them $377(74.1 \%)$ were polymorphic. The average number of fragments per primer was 63.6 and ranged from 49 (ISSR5) to 85 (ISSR3). Percentage of polymorphism ranged from 64.4 (ISSR6) to 84.3 (ISSR7). Only one RAPD marker was successfully used in the study. It generated 30 fragments of which $80.0 \%$ were polymorphic. For more details see Table 2.

Marker performance

Three coefficients were used for analysis of markers performance (PIC, MI, and RP). All characteristics of 
the markers are presented in Table 2. For each primer/ primers pair PIC value was calculated as a mean of all PIC values for all amplified fragments. The average value of PIC for AFLP markers was rather low and amounted 0.21. Maximum PIC was obtained for pairs AFLP1 and AFLP2 (0.23), while the minimum value was demonstrated by the AFLP3 (0.18). Comparison of polymorphic fragments frequency with a PIC average showed that the majority of polymorphic fragments had low PIC values. A total of 32 fragments (14\%) were characterized by a high PIC value i.e. above 0.45 , and thus they were a highly informative. The slightly higher average PIC value was observed for ISSR s (0.24). ISSR4 and ISSR7 had the highest PIC (0.26), while ISSR6 had the lowest (0.21). As many as $23 \%$ of the amplified fragments was highly informative. In the case of RAPD, tested marker was also characterized by rather moderate PIC value equal 0.25 and $23 \%$ of the amplified fragments were highly informative.

Marker Index was calculated to assess the overall usefulness of the various systems of molecular markers. The highest MI value was obtained for the set of ISSRs (8.5), and the lowest for RAPD (4.9). However, it is difficult to estimate the usefulness of RAPD based on a single primer results. Its MI value was higher than two AFLPs. Out of all the primers used in the study ISSR3 reached the maximum MI value (12.4).

The third of selected coefficients describing the performance of molecular markers, RP, points to the discriminatory potential of the set of primers. The total RP value for AFLPs amounted 64.6, and for each pair of primers ranged from 7.7 to 26.2, with an average of 16.2. For the set of eight ISSRs the total RP value was 168.1, and average per primer was equal to 21.0. The maximum RP value was obtained for ISSR3 (28.2) and the lowest for ISSR2 and ISSR5 (17.6). RP for RAPD primer was 11.6 and was higher than for two AFLP primer pairs.

\section{Morphologic diversity}

Botanical varieties were determined based on the most recent classification developed by Rodionova et al. (1994). In Avena sativa it distinguishes 32 botanical varieties on the basis of distinct morphological features such as shape of the panicle, awnedness, color of lemma, length of glumes, type of the caryopsis (naked or hulled) etc. The same classification was used at the Russian N. I. Vavilov Research Institute of Plant Industry (VIR, St. Petersburg) to describe Avena collection (Loskutov 1998). Within the collection of historical oat cultivars a total of seven botanical varieties were distinguished (aristata Krause, aurea Körn., flava Körn., grisea Körn., mutica Alef. obtusata Al., tatarica Ard.). 14 accessions were identified as a single botanical variety, in eight cases cultivars were a mixture of two and one-Kanarek Mikulicki was composed of three varieties. The botanical varieties occurred with the following frequencies: aurea (39\%), mixture mutica/aristata (35\%), mutica (9\%), grisea (9\%), flava (4\%) and a mixture tartarica/obtusata (4\%). In the group of six cultivars bred before 1914 only three botanical varieties ( tica, aurea and aristata) were described, whereas in the seventeen cultivars of the later period all seven botanical varieties were present. For details see Table 1.

The 25 examined traits had varying degrees the morphological differentiation within the collection. The diversity coefficients values within 25 morphological traits were in the range from 0 to 0.313 for Nei's genetic diversity coefficient $(\mathrm{Hj})$, and from 0 to 0.478 for Shannon Index (I.) The highest variability among tested cultivars was observed within the hairiness of basal part of the primary grain and in the length of rachilla. Three traits (erectness of spiklets, hairiness of leaf sheath, hairiness of leaf margin) demonstrated total lack of variation in the group of cultivars, six showed a faint differentiation, eight medium and eight strong. 12 of the studied traits showed a medium to strong degree of individuals' variation within the tested cultivars. Further information details about the morphological differentiation of cultivars were included in Table 3 and Fig. 1.

Genetic diversity

Both the results of molecular analysis and description of morphological traits were used to determine the level of genetic diversity within the collection of Polish common oat cultivars bred before 1939 . Graphical projection of the obtained results has been placed in Fig. 2. Genetic diversity within the entire collection, and within groups of cultivars separated on the basis of breeding period was determined using the Nei's genetic diversity coefficient $(\mathrm{Hj})$ and the Shannon Index (I). $\mathrm{Hj}$ calculated for the combined results 
Table 3 List morphological traits with the level of their diversity within the collection and individual accessions

\begin{tabular}{|c|c|c|c|}
\hline \multirow[t]{2}{*}{ Morphological trait } & \multicolumn{2}{|c|}{ Diversity within } & \multirow[t]{2}{*}{ Stages of traits } \\
\hline & Collection & Cultivars & \\
\hline Angle of flag leaf to culm & Faint & Absent & $\begin{array}{l}\text { All plants with acute leaves; } 25 \% \text { with } \\
\text { obtuse leaves; } 50 \% \ldots ; 75 \% \ldots \text {; all plants } \\
\text { with obtuse leaves }\end{array}$ \\
\hline Angle to culm of leaves & Strong & Strong & Acute; intermediate; obtuse \\
\hline Awn type & Strong & Strong & Absent; week; medium; strong; \\
\hline Awnedness & Medium & Medium & $\begin{array}{l}0-6 \% \text { no awns; } 7-15 \% \text { weak awns; } \\
16-100 \% \text { strong awns }\end{array}$ \\
\hline Axis nodes in panicle & Medium & Strong & Number \\
\hline Color of leaves & Medium & Absent & $\begin{array}{l}\text { Yellow-green; light green; green; dark green; } \\
\text { other }\end{array}$ \\
\hline Color of panicle & Faint & Absent & $\begin{array}{l}\text { Yellow-green; light green; green; dark green; } \\
\text { other }\end{array}$ \\
\hline Erectness of spikelets & Absent & Absent & Erect; drooping erect \\
\hline Growth habit & Faint & Strong & $\begin{array}{l}\text { erect; semierect; intermediate; semiprostrate; } \\
\text { prostrate }\end{array}$ \\
\hline Hairiness of basal part of the primary grain & Strong & Strong & Absent; week; medium; strong; very strong \\
\hline Hairiness of leaf margin & Absent & Absent & Absent; week; medium; strong; very strong \\
\hline Hairiness of leaf sheath & Absent & Absent & Absent; week; medium; strong; very strong \\
\hline Hairiness of lemma & Faint & Faint & Absent; week; medium; strong; very strong \\
\hline Hairiness of rachilla & Faint & Faint & Absent; week; medium; strong; very strong \\
\hline Intensity of leaves spirality & Strong & Strong & $\begin{array}{l}\text { Lack of rotation; weak rotation }(1 / 4 \text { torsion }) \text {; } \\
\text { medium rotation }(1 / 2 \text { torsion); strong } \\
\text { rotation }(3 / 4 \text { torsion }) \text {, very strong rotation } \\
\text { ( } 1 \text { torsion) }\end{array}$ \\
\hline Lemma color & Medium & Absent & White; yellow; brown; grey; black \\
\hline Length of rachilla & Strong & Strong & Very short; short; medium; long; very long \\
\hline Nodes hairiness & Medium & Strong & Absent; week; medium; strong; very strong \\
\hline Number of grains in spiklet & Medium & Strong & [number] \\
\hline Rigidity of leaves & Medium & Faint & $\begin{array}{l}\text { Erect; bent; weak dropping, dropping; } \\
\text { strongly dropping }\end{array}$ \\
\hline Shape of basal part of the primary grain & Strong & Strong & Convex; intermediate; flax \\
\hline Shape of panicle & Medium & Absent & $\begin{array}{l}\text { Erect; semi-erect; horizontal, dropping; } \\
\text { strongly dropping }\end{array}$ \\
\hline Shape of primary grain & Strong & Strong & Convex; intermediate; slender; peaked \\
\hline Spirality of leaves & Medium & Absent & Left; right \\
\hline Type of panicle & Faint & Absent & Unilateral; sub-unilateral; equilateral \\
\hline
\end{tabular}

for the entire collection was 0.202 and was significantly lower than that which has been obtained for the group of cultivars bred in the period 1918-1939 (0.230), and simultaneously considerably higher than the one that showed a group of the oldest cultivars (0.175). These differences were even more evident for Shannon Index. Morphological diversity of the whole collection cultivars was 0.188 for Nei genetic diversity coefficient and 0.281 for Shannon Index. Groups separated according to the breeding period did not differ significantly in terms of diversity coefficients, although it could be seen that the accessions bred before 1914 showed less variability. AFLP technique revealed that the diversity within two groups of cultivars was equal. These results were not confirmed by any other analysis. In accordance ISSR, RAPD and 
morphological description indicate that there was greater variability among cultivars bred in the period 1918-1939. Analogous results were obtained both by using the $\mathrm{Hj}$ and $\mathrm{I}$.

Analysis of molecular variance showed that merely if ISSR markers were used, $1 \%$ of differentiation among the two groups of cultivars separated based on the breeding period, could be reported. Likewise AMOVA based on the entire results of morphology showed also only $1 \%$ of the variance among these two groups. However, three molecular marker systems used in the presented study showed different levels of molecular variance among groups separated based on

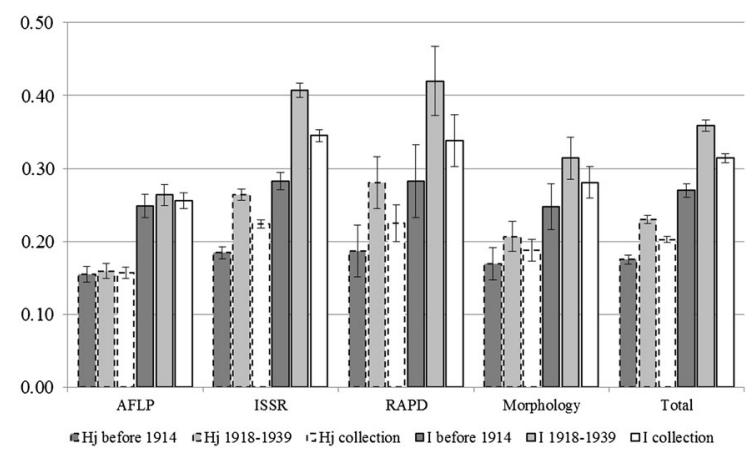

Fig. 1 The values of genetic diversity coefficient within a collection of Polish early oat cultivars for all molecular markers and morphological traits various morphological traits. The AFLP markers detected as the only ones, as many as $12 \%$ of the variance among groups differing in hairiness of lemma. In case of ISSRs differences between the groups separated based on morphological traits were not so clear. The highest variance $(5 \%)$ was detected if the groups were separated by the length of rachilla. Using a single RAPD primer it was detectable up to $10 \%$ of the molecular variance related to morphological traits (hairiness of rachilla). AMOVA carried out based on the overall results indicated the presence of $6 \%$ of the variance among three groups when the shape of primary grain was used as a selective factor. All detailed results could be obtained from Fig. 3.

Genetic distance between samples representing the cultivars was calculated based on the Dice coefficient. For the results covering the entire molecular and morphological analysis genetic distance was in the range 0.17-0.44, respectively, for the pairs of cultivars Sołacki Wczesny-Kościelecki and Zielony-Jagiełło. The largest range of distances was recorded for the AFLP markers (0.12-0.67) and the lowest for morphology (0.08-0.37). For more details please see Table 4.

All combinations of the genetic distance matrix were examined using Mantel test to determine the level of correlation. Only when the genetic distance

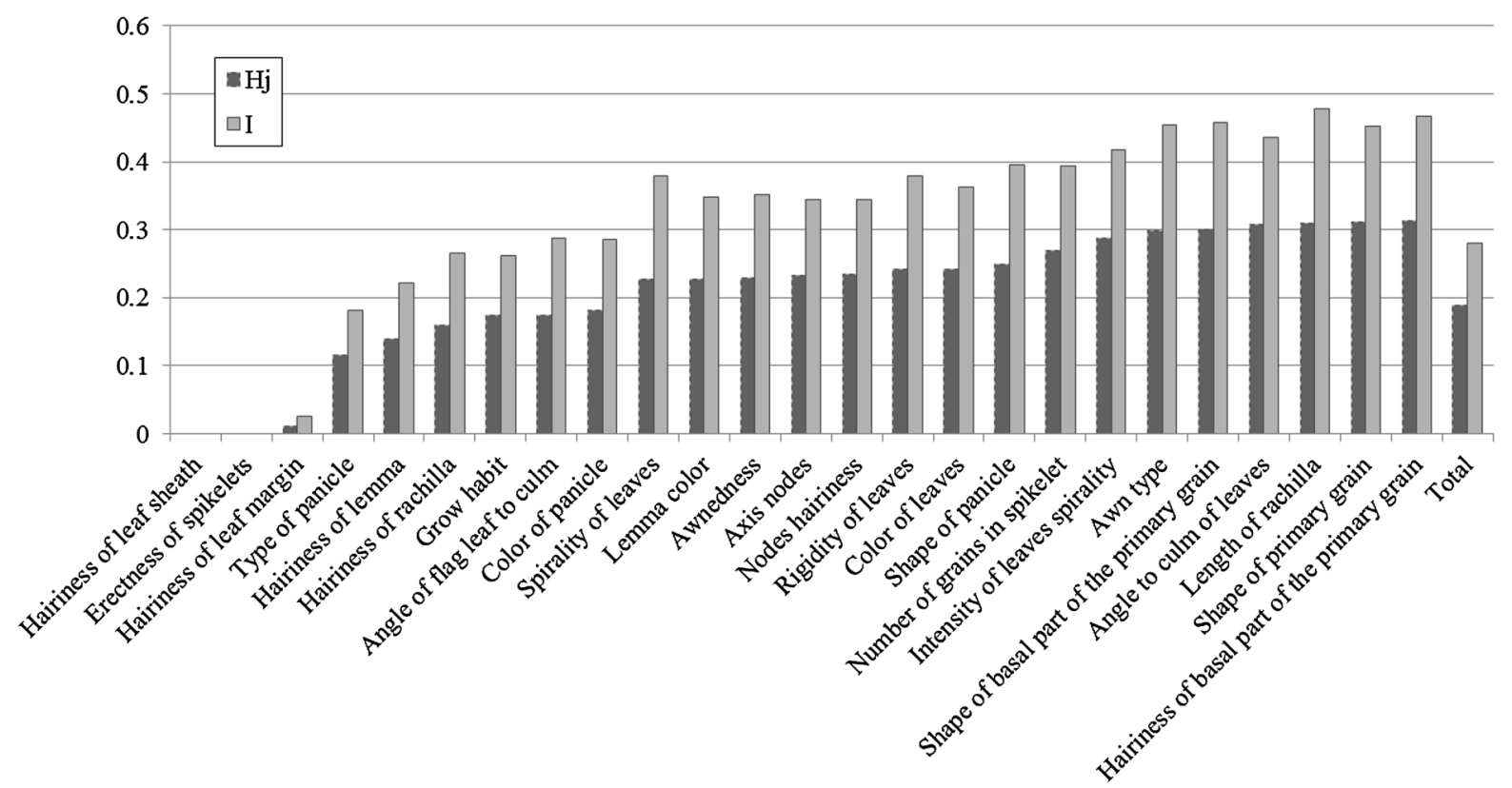

Fig. 2 The values of genetic diversity within a collection of Polish primary oat cultivars for the different morphological traits 


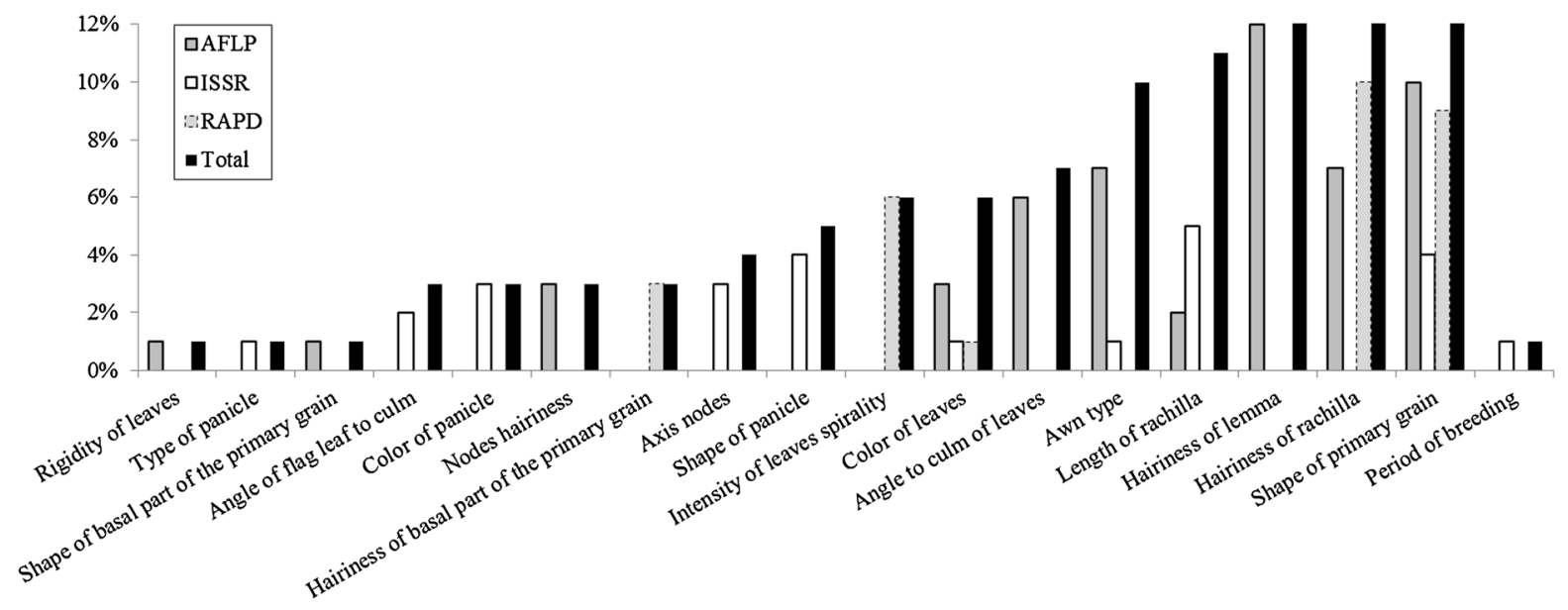

Fig. 3 Results of the analysis of molecular variance when particular morphological traits were used as the grouping criteria

Table 4 Genetic distance of Polish primary oat cultivars determined based on Dice coefficient for each technique

\begin{tabular}{|c|c|c|c|c|c|c|}
\hline \multirow[t]{3}{*}{ Technique } & \multicolumn{6}{|c|}{ Genetic distance } \\
\hline & \multicolumn{3}{|c|}{ Maximum } & \multicolumn{3}{|c|}{ Minimum } \\
\hline & Value & Access & & Value & Access & \\
\hline AFLP & 0.67 & 50975 & 51087 & 0.12 & 50869 & 51902 \\
\hline ISSR & 0.48 & 50869 & 50788 & 0.15 & 50581 & 50334 \\
\hline \multirow[t]{2}{*}{ RAPD } & 0.56 & 50406 & 51235 & 0.03 & 50581 & 51050 \\
\hline & & 51227 & 51235 & & & \\
\hline Morphology & 0.37 & 50869 & 51051 & 0.08 & 50976 & 51050 \\
\hline Total & 0.44 & 50869 & 51507 & 0.17 & 50581 & 50334 \\
\hline
\end{tabular}

matrices obtained from ISSR analysis and morphological traits description were compared, clear, statistically significant correlations was observed (Table 5).

Based on the genetic distance matrices cluster analysis UPGMA was performed. A dendrogram, created on the basis of the whole results obtained from the morphological and molecular analysis (Fig. 4.), showed the presence of both clusters with a similar level of differentiation and three accessions with higher autonomy (Ozimowy, Jagiełło and Grzywacz Późny Wołyński). The first cluster included 11 cultivars and the second one successive nine. The described clusters could not be assigned to any of the morphological traits or breeding period. Based on morphological data itself UPGMA (data not shown) also revealed the presence of two clusters and three separate objects. In both cases, distinctiveness of Grzywacz Późny Wołyński repeated, but the similarities end there.
Table 5 Mantel test results for all combinations of the genetic distance matrix

\begin{tabular}{lcc}
\hline & \multicolumn{1}{l}{$\mathrm{R}^{\mathrm{a}}$} & $p$ \\
\hline AFLP versus ISSR & -0.104 & 0.197 \\
AFLP versus RAPD & 0.103 & 0.191 \\
AFLP versus morphology & -0.079 & 0.264 \\
ISSR versus RAPD & -0.003 & 0.503 \\
ISSR versus morphology & $0.211^{*}$ & 0.028 \\
RAPD versus morphology & 0.017 & 0.425 \\
\hline
\end{tabular}

${ }^{a}$ Correlation coefficient

$* p=0.05$

Principal Coordinate Analysis was performed for the combined results of morphological and molecular analysis, as well as for the results obtained by each technique separately. Graphical projection of the results has been placed in Fig. 5. In the case of the 


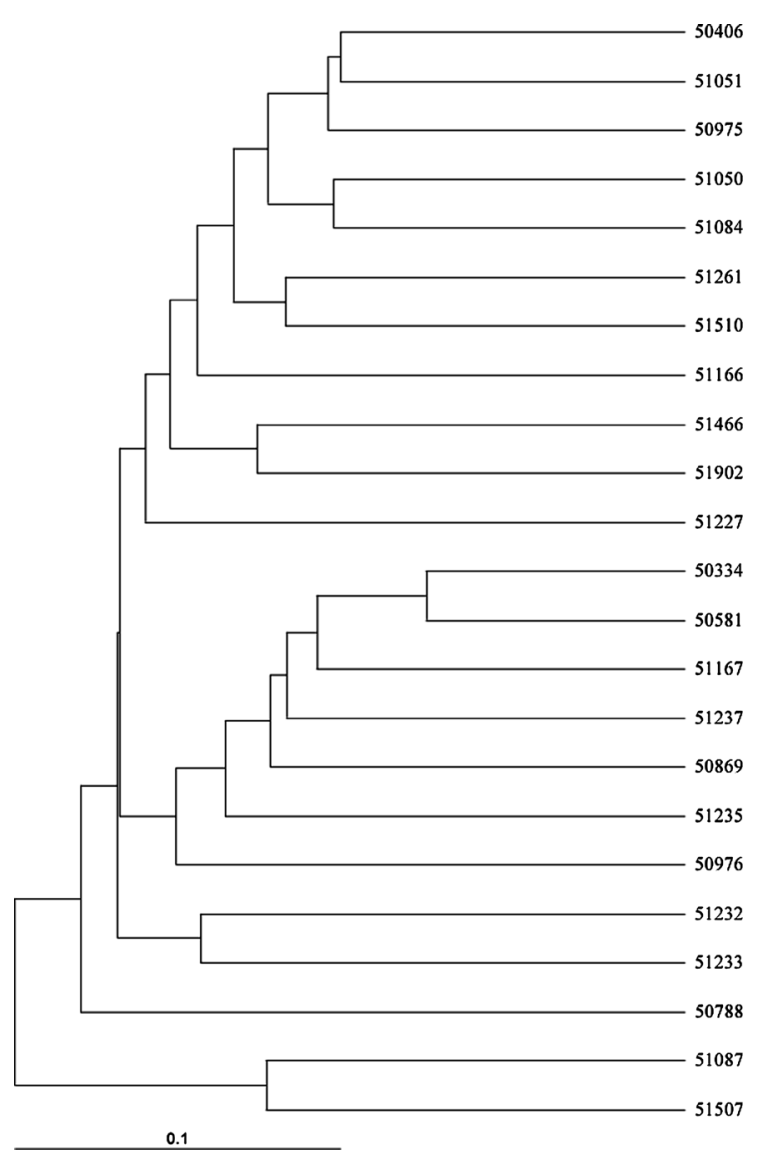

Fig. 4 Dendrogram plotted based on the results of UPGMA analysis of combined data

combined results the first three factors of PCoA explained together $43.6 \%$ of the variation $(19.9,12.4$ and $11.3 \%$ respectively). The bidimentional scatterplot (Coord. 1 vs. Coord. 2 or Coord. 1 vs. Coord. 3) did not refer the morphological traits. PCoA point's positions were similar to the distribution of cultivars on the UPGMA dendrogram. It was possible to distinguish two groups with comparable size (11 and 9) and level of diversity within them. Such an arrangement was maintained for the plot of 1 vs. 2 and 1 vs. 3 coordinates. The first three coordinates of the AFLP data exhibited $73.7 \%$ of the variance (36.6, 26.3 and $10.8 \%$, respectively). The plot of 1 vs. 2 coordinate clearly separated three groups of points of varying size and internal diversity. The first one consists of 13 cultivars, the second group of eight ones, and the third, the most separated, of twoJagiełło and Ozimowy. This three group's layout corresponds to that appeared on a UPGMA dendrogram (data not shown). In the case of the ISSR results $53.2 \%$ of the variation was explained by the first three coordinates (27.0, 15.7 and $10.5 \%$ respectively). Any connection between the point's distribution and the cultivar breeding period, or any of morphological traits was impossible to discern. Clear division into three groups composed, respectively, of twelve, six and five cultivars was delineated. Interestingly, the level of differentiation within these groups was on the similar level. These groups, as in the previous techniques corresponded to the three main UPGMA clusters. PCoA performed based on RAPD data showed the presence of one very large and two smaller groups (each consisting of two varieties). The first three coordinates explained $59.9 \%$ of the variance (28.6, 19.0 and $11.9 \%)$. Morphological data were also recorded as a $0-1$ matrix and analyzed by Principal Coordinate Analysis. $53.5 \%$ of the variation was explained by the first three coordinates $(23.8,17.5$, and $12.2 \%$ ). In this chart (Fig. 5d), the relatively highest points concentrations was noted. Despite that, separation of the three groups, which were composed of two, five and fifteen varieties, respectively, was possible.

\section{Discussion}

Selection of techniques

In studies of genetic diversity different techniques are very commonly used. In the past, morphological description has very often been used as the only source of information about genetic differentiation. Souza and Sorrells (1991) used 13 quantitative traits to describe the 70 North American cultivars and accessions, and expressed the opinion that the morphological description and results of its analysis could be a valuable source of information for breeding and agronomic research programs.

Recently, the studies of genetic diversity based mainly on the molecular analysis, sometimes combined with morphology, if it is evaluated is an additional source of information. Worldwide collections of oats were described by several types of molecular markers, for example AFLP (Fu et al. 2003, 2004, 2005), RAPD (Baohong et al. 2003), SSR (Li et al. 2000) and ISSR (Boczkowska and Tarczyk 2013). Many times more than one technique was used 
(a)
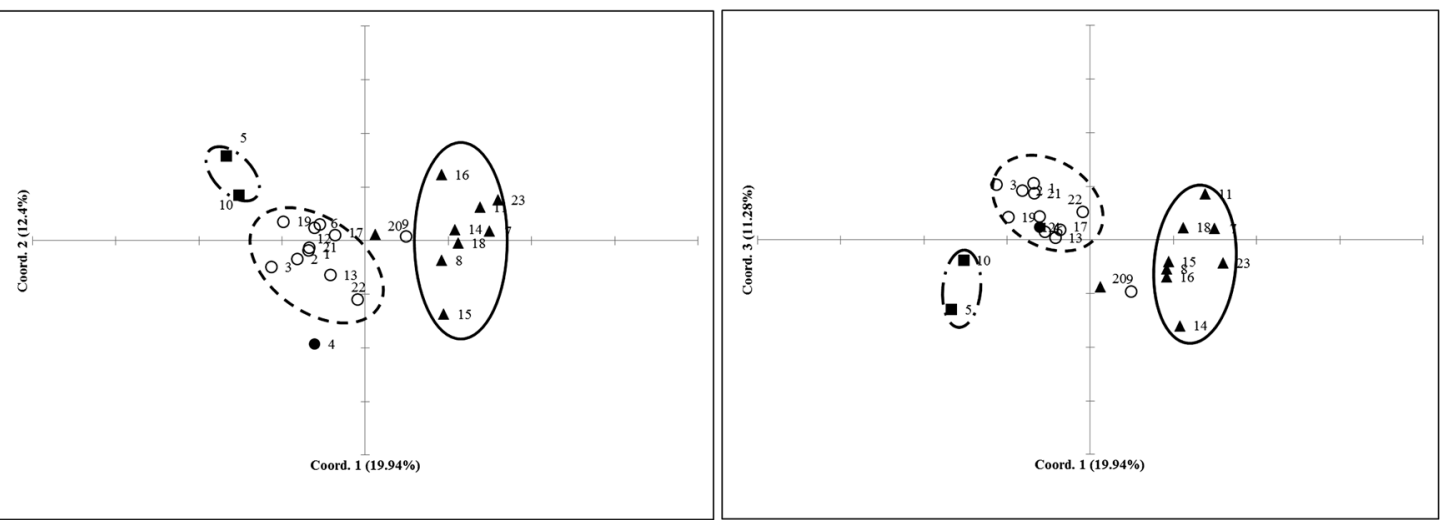

(b)

(c)
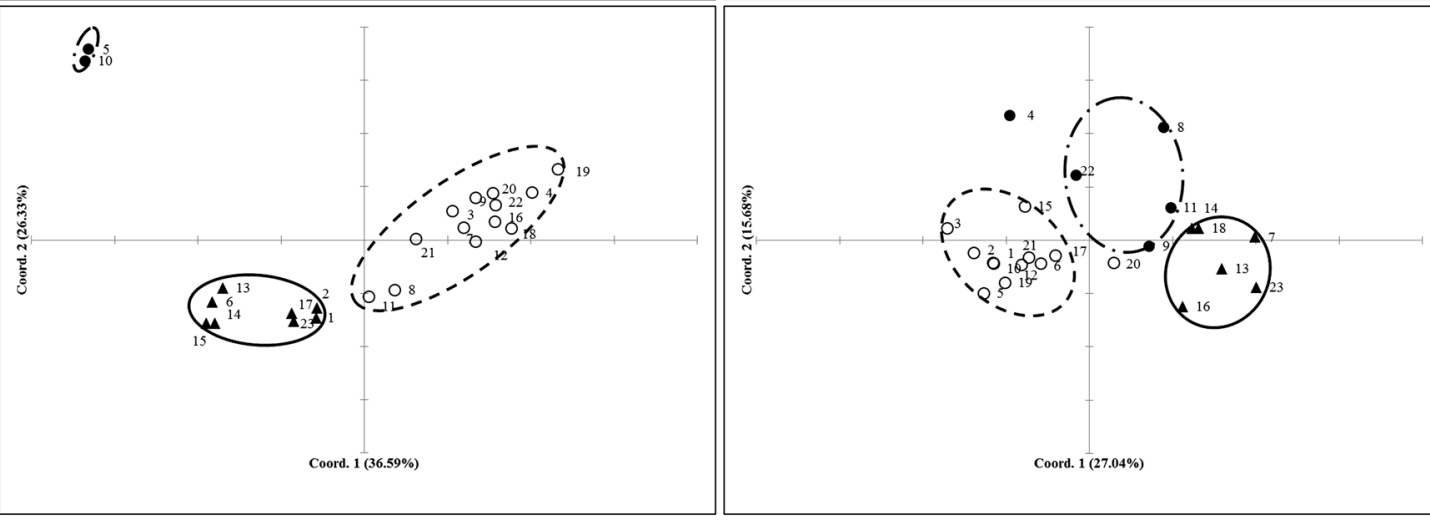

(d)

(e)

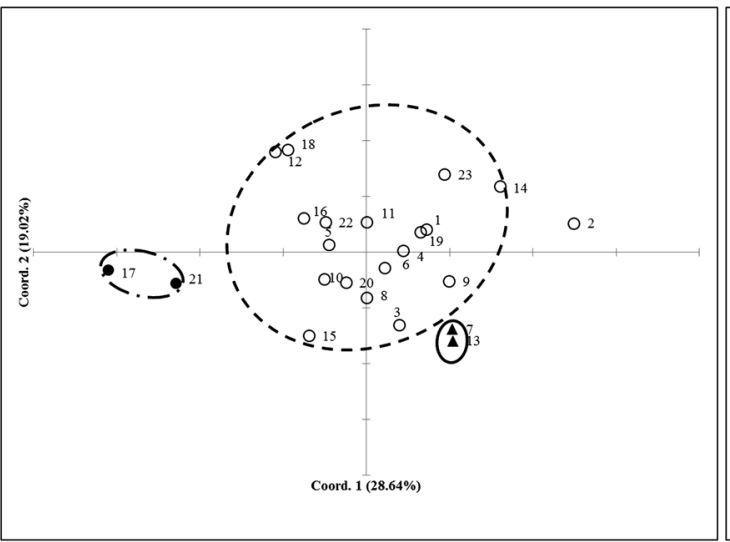

Fig. 5 Biplot of PCoA analysis of the combined data and various techniques. a, b-combined results, $\mathbf{c}$-AFLP data, $\mathbf{d}-$ ISSR data, e-RAPD data, f-morphology; cultivars on the plots were described in the following way: 1 (Antoniński Żółty), 2 (Biały Mazur), 3 (Duppawski), 4 (Grzywacz Późny Wołyńsk), 5 (Jagiełło), 6 (Kanarek Mikulicki), 7 (Kościelecki), 8

for example SSR, AFLP and DART (He and Bjørnstad 2012), AFLP and RAPD (Paczos-Grzeda 2004), AFLP and morphology (Nowosielska and Nowosielski 2008) and RAPD and SSR (Hanif et al. 2008). Usage of several techniques for this type of research allows

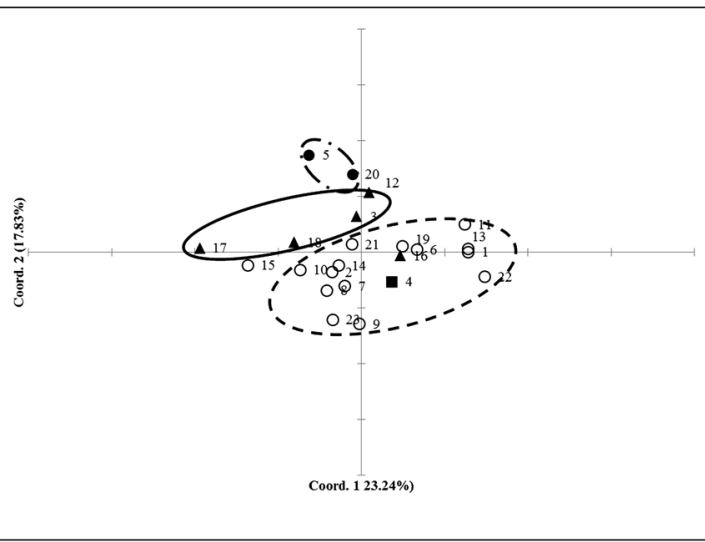

(Lubelski), 9 (Niemierczański Najwcześniejsz), 10 (Ozimowy), 11 (Podkowa Dłużewski), 12 (Puławski Średniowczesny), 13 (Puławski Wczesny), 14 (Rychlik Kozarowsk), 15 (Rychlik Oberek), 16 (Rychlik Trybańsk), 17 (Sobieszyński), 18 (Sołacki Wczesny), 19 (Tatrzański), 20 (Teodozja), 21 (Udycz Biały), 22 (Udycz Żółty), 23 (Zielony)

evaluating their effectiveness and minimizing errors. In this paper three types of molecular markers that do not require knowledge of sequences to design of primers i.e. AFLP, ISSR and RAPD, were used. Due to the relatively big problems with reproducibility of the 
RAPD technique, only one stable primer was used in the study, and it was decided to extend the research by the ISSR method. ISSR markers were successfully used in previous studies of Polish oat landrace collection (Boczkowska and Tarczyk 2013). Results of molecular analysis of the collection of old oat cultivars were complemented by morphological description. Similar, comprehensive approach to the problem was presented by Benin et al. (2008) and Nowosielska and Nowosielski (2009).

Diversity of old cultivars collection

Based on a meta-analysis it could be clearly seen that there had been dramatic decrease in genetic diversity within released cultivars of crop species in the 60's of the twentieth century (van de Wouw et al. 2010). In addition, since the middle of the last century, there had also been a continuous decline in oats acreage in the world. Both of these factors had a negative impact on the amount of in situ present and cultivated genotypes. It is considered as well that the continuous selection and breeding of closely related plants has led to a significant narrowing of the crops' gene pools. Achleitner et al. (2008), on the basis of morphological and molecular studies, reported that probably only a small fraction of available genetic diversity is used in modern breeding programs. Fu et al. (2004) obtained similar results for Canadian oat cultivars and Baohong et al. (2003) for the Chinese accessions. Leisova et al. (2007) also pointed out the way of breeding as the main culprit for the loss of genetic diversity. Hence, it becomes very important to search for good sources of genetic variation. Old cultivars could be treated as potential sources of variation that has been lost in the course of modern farming.

The level of genetic diversity of oat early cultivars was comparable to they diversity found in a collection of Polish landraces (Boczkowska and Tarczyk 2013). A similar level of differentiation was observed both on the basis of the results of the molecular and morphological analysis. Most of the results indicated a greater variation among the cultivars bred in the period 1918-1939 compared with those from the period before 1914. Only the AFLP results show no significant differences between breeding periods. This difference might be due to unequal representation of cultivars in both periods. These results were also confirmed by the analysis of genetic distance. The greatest distance was detected by AFLPs and the lowest by morphological studies. The genetic diversity of primary cultivars was higher than in contemporary Polish ones (Paczos-Grzęda 2007). However, the fact that the cultivars from the late twentieth century and from its beginning exhibited somehow similar diversity did not say anything about the integrity of their gene pools. Only juxtaposition of these accessions in a single analysis could answer unambiguously on this question.

Genetic diversity versus morphological variability

It is commonly observed that genetic variation determined by various molecular markers systems produce different results; this is due to analyzing different regions in the genome captured by the respective markers. Therefore differences could be expected in the compilation of molecular and morphological data. Morphological traits are associated with a relatively small number of loci, thus the potential difference could be lost in the analysis of large amounts of molecular data (Diederichsen 2009). In order to determine the degree of correlation of the morphological and molecular results Mantel test was performed. It showed that only ISSR markers showed statistically significant correlation with morphology. Similar results were obtained for the Polish oat landraces (Boczkowska and Tarczyk 2013). However, it must be noted that none of the techniques used in the present study were compatible during clustering with any of morphological traits neither in the PCoA nor in UPGMA analysis. This may indicate the presence of a very similar genetic background in all tested cultivars and differences within very limited important for breeding loci. However, in the above-cited studies on Polish oat landraces relationship between the color of lemma and accessions grouping on the UPGMA dendrogram had been found (Boczkowska and Tarczyk 2013). AMOVA revealed no significant differences between the cultivars bred in two separated periods, neither based on molecular nor morphological data. It showed, however, that different types of molecular markers varied in terms of comparability with morphological traits.

The analysis of genetic diversity within a world collection of cultivated hexaploid oat based on morphological characters showed the presence of 118 morphological groups and the Polish accessions 
were classified as 15 groups and it was the most diverse collection in the region (Diederichsen 2008). In the studied collection of primary cultivars seven botanical varieties such as: aristata, aurea, flava, grisea, mutica, obtustata and tartarica were identified. The collection of Polish landraces was also composed of seven botanical varieties (Nowosielska and Nowosielski 2009; Boczkowska and Tarczyk 2013), but these two collections were different. In the primary cultivars collection a very morphologically interesting accession occurred composed of individuals belonging to a varieties obtustata and tartarica (Zielony). Although this cultivar was bred from landrace which had been grown on Polish territory, it is difficult to find this type of accession in the collection of Polish landraces. On the other hand, there were no accessions classified as varieties cinerea and krausei in the collection of old cultivars. On the basis of both collections mentioned above it could be clearly seen that some old genotypes that were grown as local forms were not preserved and had been irreversibly lost. The positive fact is that in spite of all this, the landraces genetic differentiation is greater than that of the cultivars (Nowosielska 2006). Thus, both collections could be a valuable source of alleles absent in modern genotypes that could be used in modern breeding programs. However, according to the monitoring of accession sharing conducted by national genebank maintained by National Center of Plant Genetic Resources in the Plant Breeding and Acclimatization Institute-National Research Institute, breeders' interest in primary cultivars and landraces was and still is negligible.

\section{Marker usefulness}

During selection of analysis methods efficiency, informativeness, reproducibility of the results and the costs should be taken into account. Usefulness of markers is described mainly through the percentage of polymorphic fragments. The highest percentage of polymorphic fragments was characterized by RAPD. However, due to using only one primer, it was difficult to generalize this result. Two other types of markers also demonstrated very high level of polymorphism. In previous studies within oats collection such a high level of polymorphism was not observed. Fu et al. (2003) in the studies of Canadian oat forms had received only $42.8 \%$ of polymorphic AFLP fragments. Almost the same level of AFLP polymorphism received Paczos-Grzeda (2004). For ISSR markers participation of polymorphic fragments in the oat collections ranged from $41.7 \%$ (PaczosGrzęda 2007) to $59.3 \%$ (Boczkowska and Tarczyk 2013). The efficiency of molecular markers could be assessed with such parameters as PIC, MI and RP. PIC coefficient is relatively often used to assess the potential of molecular markers information. For dominant markers it ranges from 0 to 0.5 . In the present study PIC values obtained for the AFLP markers were rather low $0.18-0.23$, with an average 0.21 , and were lower than those obtained for durum wheat cultivars released in Italy and Spain throughout twentieth century. The values for the individual primer pairs ranged there from 0.23 to 0.41 with an average 0.34 (Martos et al. 2005). Also, in the case of 19 genotypes of common wheat the coefficient values were higher (0.32-0.39, average 0.36) (Vieira et al. 2007). However, in the case of Syrian bread and durum wheat cultivars collection, the PIC values for AFLP were a much lower (0.053-0.273) with an average of 0.195 (Saleh 2012). PIC values for Chinese core collection of $A$. nuda L. were also significantly lower (0.0098-0.0639, mean 0.0326) (Wei et al. 2009) than these obtained in our study. ISSR markers used in the present study were characterized by a slightly higher value of the PIC than that obtained for AFLP. Comparable results were obtained when the same set of primers was used in the study of Polish oat landraces (Boczkowska and Tarczyk 2013). Also for goatgrass (Thomas and Bebeli 2010) and wheat (Najaphy et al. 2012) comparable values of PIC were received. The only RAPD primer used in the study was characterized by PIC value equal to 0.25 and it was significantly higher than the average PIC value obtained for Syrian wheat cultivars (Saleh 2012). However, the values of this ratio in the cited above studies were highly variable, and two out of 20 tested primers had reached PIC values comparable to our ones (Saleh 2012). Low PIC values for all types of molecular markers used the in studies resulted mainly from high percentages of fragments of very low and very high frequencies (AFLP-61\%, ISSR-47\%, RAPD-35 \%).

The MI could be considered as an overall measure of marker utility. In the presented study it varied between 2.75 for AFLP2 and 12.35 for ISSR3. The average AFLP MI was comparable with values 
obtained in previous studies, for example on barley (Varshney et al. 2007), durum wheat (Martos et al. 2005) and soybean (Powell et al. 1996). In the case of ISSR, the MI value was twofold higher than those described earlier for rice (Davierwala et al. 2000), cashew (Archak et al. 2003) and bitter gourd (Behera et al. 2008). In numerous studies, where the AFLP and ISSR markers were compared, higher value of MI was typical for AFLP. In the case of the presented results, the opposite situation occurred. Higher average value of ISSR MI was undoubtedly related to the application of more sensitive methods of separation and detection by using capillary electrophoresis, which multiplied the amount of data received after PCR.

Resolving power was for the first time described by Prevost and Wilkinson (1999) as a measure of discriminatory power of a molecular marker. One of the most valuable features of molecular markers used in studies of genetic differentiation is the ability to distinguish between different accessions. RP seems to be the perfect coefficient to analyse such ability. In the presented studies RP values ranged from 7.74 (AFLP2) to 28.17 (ISSR3). The average value of RP for AFLPs was 16.15 and was lower than the average of ISSRs (21.01). The obtained values indicate the two studied markers systems had the potential to distinguish the tested accessions. Interestingly, the RP value for the RAPD primer also pointed to its potential ability to distinguish all tested cultivars. RP values were confirmed by determining the number of genotypes identified by the various markers (data not shown). In the literature, this factor took on different values depending on the primers used and diversity of test collections egg. 23.707 for AFLP in sweet sorghum (Pecina-Quintero et al. 2012); 73.0 for AFLP in tea (Kafkas et al. 2009); 9.79 for ISSR in barley (Fernández et al. 2002); 7.67 for ISSR in rice (Reddy et al. 2009). The whole above information indicated that, out of the molecular markers used in the study, ISSRs were the most useful.

Comparative analysis of three systems of molecular markers AFLP, ISSR and RAPD showed that the set of ISSRs was the most efficient. The ISSRs were also highly reproducible and had a relatively low cost. Only this type of markers showed a statistically significant correlation with morphological data, therefore it is recommended for evaluation of other oat collections. The presented study demonstrated that the collection of Polish oat cultivars bred before 1939 could be a really valuable source of variability. Part of morphological diversity that has been preserved in the Polish early oat cultivars, do not exist anymore in contemporary cultivars, and also in landraces.

Acknowledgments The authors would like to express their utmost gratitude to Bogusław Łapiński, for his constructive remarks. The greatest thanks to Zofia Bulińska-Radomska, head of National Centre for Plant Genetic Resources, IHAR-PIB, who created the capacity to perform the research presented in this paper. In memory of Janina Dunińska, without whose mental support this study would be much more difficult.Open Access This article is distributed under the terms of the Creative Commons Attribution License which permits any use, distribution, and reproduction in any medium, provided the original author(s) and the source are credited.

\section{References}

Achleitner A, Tinker N, Zechner E, Buerstmayr H (2008) Genetic diversity among oat varieties of worldwide origin and associations of AFLP markers with quantitative traits. Theor Appl Genet 117:1041-1053. doi:10.1007/s00122008-0843-y

Archak S, Gaikwad AB, Gautam D, Rao EVVB, Swamy KRM, Karihaloo JL (2003) Comparative assessment of DNA fingerprinting techniques (RAPD, ISSR and AFLP) for genetic analysis of cashew (Anacardium occidentale L.) accessions of India. Genome 46:362-369. doi:10.1139/ g03-016

Baohong G, Zhou X, Murphy JP (2003) Genetic variation within Chinese and Western cultivated oat accessions. Cereal Res Commun 31:339-346

Behera TK, Gaikward AB, Singh AK, Staub JE (2008) Relative efficiency of DNA markers (RAPD, ISSR and AFLP) in detecting genetic diversity of bitter gourd (Momordica charantia L.). J Sci Food Agric 88:733-737. doi:10.1002/jsfa

Benin G, de Carvalho FIF, de Oliveira AC, Marchioro VS, Vieira EA, Bertan I, Valério IP, Marchese JA, Matei G (2008) Morphological and AFLP markers for describing genetic relationships among white-oat genotypes. Bragantia 673:563-568

Boczkowska M, Tarczyk E (2013) Genetic diversity among Polish landraces of common oat (Avena sativa L.). Genet Resour Crop Evol. doi:10.1007/s10722-013-9984-1

Boczkowska M, Bulińska-Radomska Z, Nowosielski J (2012) AFLP analysis of genetic diversity in five accessions of Polish runner bean (Phaseolus coccineus L.). Genet Resour Crop Evol 59:473-478. doi:10.1007/s10722-012-9798-6

Brown AHD, Weir BS (1983) Measuring genetic variability in plant populations. In: Tanksley SD, Orton TJ (eds) Isozymes in plant genetics and breeding. Elsevier, Amsterdam, pp 219-239

Davierwala AP, Chowdari KV, Kumar S, Reddy APK, Ranjekar PK, Gupta VS (2000) Use of three different marker systems to estimate genetic diversity of Indian elite rice varieties. Genetica 108:269-284. doi:10.1023/A:1004160232679 
Diederichsen A (2008) Assessments of genetic diversity within a world collection of cultivated hexaploid oat (Avena sativa L.) based on qualitative morphological characters. Genet Resour Crop Evol 55:419-440. doi:10.1007/s10722-0079249-y

Diederichsen A (2009) Duplication assessments in Nordic Avena sativa accessions at the Canadian national genebank. Genet Resour Crop Evol 56:587-597. doi:10.1007/ s10722-008-9388-9

Excoffier L, Smouse P, Quattro J (1992) Analysis of molecular variance inferred from metric distances among DNA haplotypes: application to human mitochondrial DNA restriction data. Genetics 131:479-491

Fernández ME, Figueiras AM, Benito C (2002) The use of ISSR and RAPD markers for detecting DNA polymorphism, genotype identification and genetic diversity among barley cultivars with known origin. Theor Appl Genet 104:845-851. doi:10.1007/s00122-001-0848-2

Fu YB, Peterson GW, Scoles G, Rossnagel B, Schoen DJ, Richards KW (2003) Allelic diversity changes in 96 Canadian oat varieties released from 1886 to 2001. Crop Sci 43:1989-1995. doi:10.2135/cropsci 2003.1989

Fu YB, Kibite S, Richards KW (2004) Amplified fragment length polymorphism analysis of 96 Canadian oat varieties released between 1886 and 2001. Can J Plant Sci 84:23-30

Fu YB, Peterson GW, Williams D, Richards KW, Fetch MJ (2005) Patterns of AFLP variation in a core subset of cultivated hexaploid oat germplasm. Theor Appl Genet 111:530-539. doi:10.1007/s00122-005-2044-2

Hanif Z, Swati ZA, Khan I, Hassan G, Marwat KB, Ali S, Khan MI (2008) RAPD and SSR analysis of wild oats (Avena species) from North West frontier province of Pakistan. Afr J Plant Sci 11:133-139

He X, Bjørnstad A (2012) Diversity of North European oat analyzed by SSR, AFLP and DArT markers. Theor Appl Genet 125:57-70. doi:10.1007/s00122-012-1816-8

IBPGR (1985) Oat descriptors. International Board for Plant Genetic Resources, Rome

Jasińska Z (2003) Szczegółowa uprawa roślin. Wyd. AR Wrocław, Wrocław

Kafkas S, Ercisxli S, Dogan Y, Erturk Y, Haznedar A, Sekban R (2009) Polymorphism and genetic relationships among tea genotypes from Turkey revealed by amplified fragment length polymorphism markers. J. Am Soc Hortic Sci 134:428-434

Ladizinski G (1988) The domestication and history of oats. 7-12. Proceedings of 3rd international oat conference. Lund, Sweden, 4-8 July 1988

Leggett JM, Thomas H (1995) Oat evolution and cytogenetics. In: Welch RW (ed) The oat crop. Chapman and Hall, London, pp 120-149

Leisova L, Kucera L, Dotlacil L (2007) Genetic resources of barley and oat characterized by microsatellites. Czech J Genet Plant Breed 43:97-104

Li CD, Rossnagel BG, Scoles GJ (2000) The development of oat microsatellite markers and their use in identifying relationships among Avena species and oat varieties. Theor Appl Genet 101:1259-1268. doi:10.1007/s001220051605

Loskutov IG (1998) Database and taxonomy of VIR's world collection of the genus Avena L. In: Maggioni L, Legget M, Bücken S, Lipman E (compilors) Report of a working group on Avena; Fifth meeting, Vilnius, Lithuania, 7-9 May 1998. International Plant Genetic Resources Institute, Rome, pp 26-31

Loskutov IG (2008) On evolutionary pathways of Avena species. Genet Resour Crop Evol 55:211-220. doi:10.1007/ s10722-007-9229-2

Lynch M, Milligan BG (1994) Analysis of population genetic structure with RAPD markers. Mol Ecol 3:91-99

Mantel N (1967) The detection of disease clustering and a generalized regression approach. Cancer Res 27:209-220

Martos V, Royo C, Rharrabti Y, Garcia del Moral LF (2005) Using AFLPs to determine phylogenetic relationships and genetic erosion in durum wheat cultivars released in Italy and Spain throughout the 20th century. Field Crops Res 91:107-116. doi:10.1016/j.fcr.2004.06.003

Murray AA, Thompson WF (1980) Rapid isolation of high molecular weight plant DNA. Nucl Acids Res $8: 4321-4325$

Najaphy A, Parchin RA, Farshadfar E (2012) Comparison of phenotypic and molecular characterizations of some important wheat cultivars and advanced breeding lines. Aust J Crop Sci 6:326-332

Nei M (1978) Estimation of average heterozygosity and genetic distance from a small number of individuals. Genetics 89:583-590

Nowosielska D (2006) Różnorodność genotypowa i morfologiczna odmian i populacji miejscowych owsa (Avena sativa L.) uprawianych w Polsce (Genotypic and morphological diversity of cultivars and landraces of oats (Avena sativa L.) cultivated in Poland). Ph D. Thesis Plant Breeding and Acclimatization Institute

Nowosielska D, Nowosielski J (2008) Morphological diversity and DNA polymorphism of common oat (Avena sativa L.) landraces cultivated in Poland. Plant Breed Seed Sci 58:11-22

Nowosielska D, Nowosielski J (2009) Morphological diversity and DNA Polymorphism of common oat (Avena sativa L.) breeding varieties cultivated in Poland. Plant Breed Seed Sci $60: 31-40$

Paczos-Grzeda E (2004) Pedigree, RAPD and simplified AFLPbased assessment of genetic relationships among Avena sativa L. varieties. Euphytica 138:13-22. doi:10.1023/B: EUPH.0000047055.99322.7a

Paczos-Grzęda E (2007) Wykorzystanie metod ISSR i RAPD oraz analizy rodowodów do oceny podobieństwa międzyodmianowego Avena sativa. Zesz Probl Post Nauk Rol 517:547-558

Page R (1996) TREEVIEW: an application to display phylogenetic trees on personal computers. Comput Appl Biosci 12:357-358

Peakall R, Smouse PE (2012) GenAlEx 6.5: genetic analysis in Excel. Population genetic software for teaching and research—an update. Bioinformatics. doi:10.1093/ bioinformatics/bts 460

Pecina-Quintero V, Anaya-López JL, Zamarripa-Colmenero A, Montes-García N, Nuñez-Colín C, Solis-Bonilla JL, Aguilar-Rangel MR, Prom L (2012) Genetic diversity of sweet sorghum germplasm in Mexico using AFLP and SSR markers. Pesq Agropec Bras 47:1095-1102

Powell W, Morgante M, Andre C, Hanafey M, Vogel J, Tingey S, Rafalski A (1996) The comparison of RFLP, RAPD, 
AFLP and SSR (microsatellite) markers for germplasm analysis. Mol Breed 2:225-238. doi:10.1007/BF00564200

Prevost A, Wilkinson MJ (1999) A new system of comparing PCR primers applied to ISSR fingerprinting of potato cultivars. Theor Appl Genet 98:107-112. doi:10.1007/ s001220051046

Reddy CS, Babu AP, Swamy BPM, Kaladhar K, Sarla N (2009) ISSR markers based on GA and AG repeats reveal genetic relationship among rice varieties tolerant to drought, flood, or salinity. J Zhejiang Univ Sci B10:133-141. doi:10.1631/ jzus.B0820183

Rodionova NA, Soldatov VN, Merezhko VE, Jarosh NP, Kobyljanskij VL (1994) Flora of cultivated plants. Kolos, Moscow

Roldan-Ruiz I, Dendauw J, Van Bockstaele E, Depicker A, De Loose M (2000) AFLP markers reveal high polymorphic rates in ryegrasses (Lolium spp.). Mol Breed 6:125-134. doi:10.1023/A:1009680614564

Saleh B (2012) Biochemical and genetic variation of some Syrian wheat varieties using NIR, RAPD and AFLPs techniques. J Plant Biol Res 1:1-11

Schlüter P, Harris S (2006) Analysis of multilocus fingerprinting data sets containing missing data. Mol Ecol Notes 6:569-572. doi:10.1111/j.1471-8286.2006.01225.x

Slabonski A (1949) Odmiany owsa. Biblioteka Puławska nr 49. Państwowy Instytut Wydawnictw Rolniczych

Souza E, Sorrells ME (1991) Relationships among 70 North American oat germplasm: I. Cluster analysis using quantitative characters. Crop Sci 31:599-605

Świerczewski A, Mazaraki M (1993) Hodowla owsa. In: Mazurek J, Wojcieska U, Mazurek J, Król M (eds) Biologia i agrotechnika owsa. IUNG, Puławy, pp 129-161
Thomas K, Bebeli P (2010) Genetic diversity of Greek Aegilops species using different types of nuclear genome markers. Mol Phylogenet Evol 56:951-961. doi:10.1016/j.ympev. 2010.04.041

UPOV (1994) Guidelines for the conduct of tests for distinctness, uniformity and stability. Oats. TG/20/10

van de Wouw M, van Hintum T, Kik C, van Treuren R, Visser B (2010) Genetic diversity trends in twentieth century crop cultivars: a meta analysis. Theor Appl Genet 120:1241-1252. doi:10.1007/s00122-009-1252-6

Varshney RK, Chabane K, Hendre PS, Aggarwal RK, Graner A (2007) Comparative assessment of EST-SSR, EST-SNP and AFLP markers for evaluation of genetic diversity and conservation of genetic resources using wild, cultivated and elite barleys. Plant Sci 173:638-649. doi:10.1016/j. plantsci.2007.08.010

Vavilov NI (1992) Origin and geography of cultivated plants. Cambridge University Press, Cambridge

Vieira EA, de Carvalho FIF, Bertan I, Kopp MM, Zimmer PD, Benin G, da Silva AG, Hartwig I, Malone G, de Oliveira AC (2007) Association between genetic distances in wheat (Triticum aestivum L.) as estimated by AFLP and morphological markers. Genet Mol Biol 30:392-399

Warburton CW (1910) Oats: growing the crop. Farmers Bull 424:5-6

Wei X, Zong-Wen Z, Bin W, Lin C (2009) Genetic diversity in naked oat (Avena nuda) germplasm revealed by AFLP markers. Acta Agron Sin 35:2205-2212

Wiśniewska I, Rafalski A (2006) Location of markers of aluminium tolerance genes on rye chromosomes (Secale cereale L.). Plant Breed Seed Sci 53:43-52 